\title{
Hampton's hump
}

\author{
Annabelle Machin, ${ }^{1}$ Gurmit Gill, ${ }^{1}$ Joseph M Pappachan ${ }^{2}$
}

${ }^{1}$ Department of Endocrinology, University Hospital of North Staffordshire, Stoke-on-Trent, UK

${ }^{2}$ Department of Endocrinology, Diabetes \& Metabolism, UHNS, Stoke-on-Trent, UK

\section{Correspondence to} Dr Joseph M Pappachan, drpappachan@yahoo.co.in
CrossMark

\footnotetext{
To cite: Machin A, Gill G, Pappachan JM. BMJ Case Rep Published online:

[please include Day Month Year] doi:10.1136/bcr-2013201789
}

\section{DESCRIPTION}

A 53-year-old man presented to the emergency department with right-sided pleuritic chest pain and mild haemoptysis. His medical history included inferior wall myocardial infarction managed by coronary artery stenting and aortoiliac stenosis managed medically. Risk factors for venous thromboembolism were not identified. Physical examination was unremarkable. A chest radiograph and ECG did not show any abnormalities. The only abnormal blood test reported was a slightly elevated D-dimer of $469 \mu \mathrm{g} / \mathrm{L}$ (normal range 30 380). A CT pulmonary angiogram revealed a right lower lobe pulmonary embolus (PE) extending through to the posterobasal segment (figure 1, arrow) with ground glass change in the posterior costophrenic gutter in keeping with a prominent Hampton's hump (figure 2, arrow). An ultrasound scan of the abdomen and pelvis did not reveal a source of venous thromboembolism. He was discharged after warfarinisation with a plan to continue anticoagulation for 6 months.

Hampton's hump is a radiological sign consisting of a peripheral, wedge-shaped opacification adjacent to the pleural surface, which represents pulmonary infarction distal to a pulmonary embolus. ${ }^{1}$ Owing to good pulmonary perfusion from collateral blood vessels, this sign is rarely seen in clinical practice. Pulmonary infarction usually occurs in patients with large PE and in those with pre-existing lung disease. Pre-existing vascular disease in the collateral circulation (note the history of myocardial infarction and aortoiliac disease in this patient) might explain a pulmonary infarction even with a relatively small PE in this case. Westermark's sign of regional oligaemia and Fleischner's sign of central

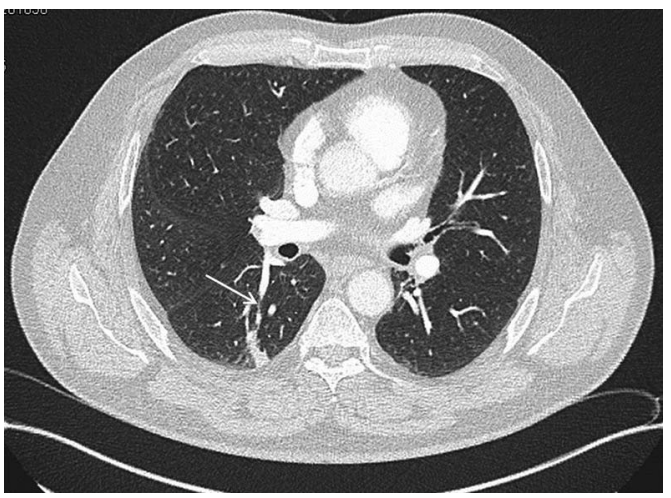

Figure 1 CT pulmonary angiogram (CTPA) showing the embolus within lower lobe segmental pulmonary artery (arrow).

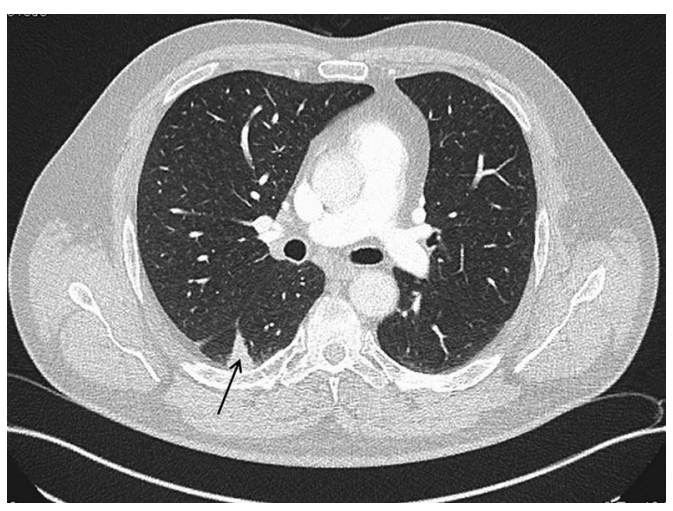

Figure 2 CT pulmonary angiogram showing the wedge-shaped subpleural pulmonary infarction (Hampton's hump; arrow).

pulmonary artery dilation secondary to an embolus are the other radiological signs of a pulmonary embolism. $^{23}$

\section{Learning points}

- Hampton's hump is an unusual radiological sign of pulmonary embolism that results from a subpleural wedge-shaped pulmonary infarction.

- Pulmonary infarction is infrequently observed in clinical practice because of the rich collateral blood circulation in the lungs.

- Other uncommon radiological signs observed in pulmonary embolism are Westermark's sign of regional oligaemia and Fleischner's sign of central pulmonary artery dilation.

Contributors All the authors contributed to the case work-up writing the manuscript and editing it in the final form.

Competing interests None.

Patient consent Obtained.

Provenance and peer review Not commissioned; externally peer reviewed.

\section{REFERENCES}

1 McGraph BM, Groom AG. Hampton's hump. New Engl I Med 2013;368:2219.

2 Worsley DF, Alavi A, Aronchick JM, et al. Chest radiographic findings in patients with acute pulmonary embolism: observations from the PIOPED study. Radiology 1993;189:133-6.

3 Reidel M. Diagnosing pulmonary embolism. Postgrad Med J 2004;80:309-19. 
Copyright 2013 BMJ Publishing Group. All rights reserved. For permission to reuse any of this content visit http://group.bmj.com/group/rights-licensing/permissions.

BMJ Case Report Fellows may re-use this article for personal use and teaching without any further permission.

Become a Fellow of BMJ Case Reports today and you can:

- Submit as many cases as you like

- Enjoy fast sympathetic peer review and rapid publication of accepted articles

- Access all the published articles

- Re-use any of the published material for personal use and teaching without further permission

For information on Institutional Fellowships contact consortiasales@bmjgroup.com

Visit casereports.bmj.com for more articles like this and to become a Fellow 